\title{
Encapsulation of cancer signalling pathway inhibitors as a protective way for healthy cells
}

\author{
Nemany AN Hanafy ${ }^{1,2 *}$ \\ ${ }^{1}$ Sohag Cancer Center, Egypt \\ ${ }^{2}$ Institute of Nanoscience and Nanotechnology, Kafrelsheikh University, Egypt
}

Encapsulation of cancer drugs in a single carrier has become one of most interesting topic, especially for those drugs that have inhibitor effect on signaling pathways. Among many investigated cellular pathways, transforming growth factors (TGF $\beta$ ) exhibit cellular efficiency in case of health and diseases due to their roles in differentiation, growth and cytoskeleton morphology [1]. However, in tumor cells TGF- $\beta$ looses anti-proliferative response and become an oncogenic factor helping cancer cells to be more invasive and keen to metastasis [2]. Blocking of TGF $\beta$ signaling pathways belong to the most promising therapeutic concepts which are currently under development and mostly are in phase II clinical trials. Although these inhibitors are efficient, they are partially used because their inhibition can cause major complications on normal cells [3]. On other side, cellular structure of cancer cells exhibit drug resistance due to the plasma membrane P-glycoprotein which is capable of repel drugs from the cell, it causes a decreased sensitivity and intracellular drugs accumulation [4]. For all of these complications, there is an urgent need to develop new and innovative technologies that could help to overcome the limits of current chemotherapy. In recent work, the encapsulation of chemotherapy has emerged as the last development for modern bio-nanotechnology. The micro- and nano-encapsulation is a process that consists of the enveloping of cargo compounds inside layer-by-layer assembly [5], protecting them from the external environment or from the adverse conditions and enabling their controlled release. This will improve oral drug delivery usage. To block TGF $\beta 1$ signaling pathways, Activin like kinase (ALK1) [6], LY2157299 (LY) [7], siRNAs, shDNA, peptide 17 [8] were encapsulated, in addition to Bromopyruvic acid (3-BrPA) as glycolytic inhibitor $[9,10]$.

\section{References}

1. Derynck R, Akhurst RJ, Balmain A (2001) TGF-beta signaling in tumor suppression and cancer progression. Nat Genet 29: 117-129. [Crossref]

2. Kubiczkova L, Sedlarikova L, Hajek R, Sevcikova S (2012) TGF- $\beta$ - an excellent servant but a bad master. $J$ Transl Med 10:183. [Crossref]

3. Mitchell D, Pobre EG, Mulivor AW, Grinberg AV, Castonguay R, et al. (2010) ALK1Fc inhibits multiple mediators of angiogenesis and suppresses tumor growth. Mol Cancer Ther 9: 379-388. [Crossref]

4. Krishna R, Mayer LD (2000) Multidrug resistance (MDR) in cancer: Mechanisms, reversal using modulators of MDR and the role of MDR modulators in influencing the pharmacokinetics of anticancer drugs. Eur J Pharm Sci 11: 265-283. [Crossref]

5. Hanafy NA, De Giorgi ML, Nobile C, Rinaldi R, Leporatti S (2015) Control of Colloidal $\mathrm{CaCO} 3$ suspension by using biodegradable polymers during fabrication. Beni-Suef University Journal of Basic and Applied Sciences 4: 60-70.

6. Hanafy NA, Ferraro MM, Gaballo A, Dini L, Tasco V, et al. (2016) Fabrication and characterization of ALK1fc-loaded fluoro-magnetic nanoparticles for inhibiting TGF B1 in hepatocellular carcinoma. RSC Adv 6: 48834-48842.

7. Hanafy NA, Nobile C, De Giorgi ML, Ran B, Cao Y, et al. (2014) LY2157299-Loaded Carriers Inhibiting Wound Healing in Hepatocellular Carcinoma. J Biotech 185S: S18-S36.

8. Hanafy NAN, Quarta A, Di Corato R, Dini L, Nobile C, et al. (2017) Hybrid PolymericProtein Nano-Carriers (HPPNC) for Targeted Delivery of TGF B1 Inhibitors to Hepatocellular Carcinoma Cells. J Mater Sci Mater Med 28: 120. [Crossref]

9. Hanafy NAN, De Giorgi ML, Nobile C, Cascione MF, Rinaldi R, et al. (2016) CaCO3 rods as chitosan-polygalacturonic acid carriers for bromopyruvic acid delivery. Sci $A d v$ Mater 8: 514-523.

10. Hanafy NA, Dini L, Citti C, Cannazza G, Leporatti S (2018) Inhibition of Glycolysis by Using a Micro/Nano-Lipid Bromopyruvic Chitosan Carrier as a Promising Tool to Improve Treatment of Hepatocellular Carcinoma. Nanomaterials (Basel) 8: 1. [Crossref]
Copyright: (C)2018 Hanafy NAN. This is an open-access article distributed under the terms of the Creative Commons Attribution License, which permits unrestricted use, distribution, and reproduction in any medium, provided the original author and source are credited.
${ }^{*}$ Correspondence to: Nemany AN Hanafy, Institute of Nanoscience and Nanotechnology, Kafrelsheikh University, 33516 Kafr ElSheikh, Egypt, E-mail: nemany.hanafy@gmail.com / nemany.hanafy@nanotec.cnr.it

Received: February 27, 2018; Accepted: April 21, 2018; Published: April 25, 2018 